\title{
ASPECTS OF LEAF ANATOMY OF KUDZU (PUERARIA LOBATA, LEGUMINOSAE-FABOIDEAE) RELATED TO WATER AND ENERGY BALANCE`
}

\author{
ADAUCTO BELLARMINO DE PEREIRA-NETTO ${ }^{2}$, ANTONIO CARLOS GABRIELE ${ }^{3}$ and HILTON SILVEIRA PINTO ${ }^{4}$
}

\begin{abstract}
Kudzu is a cover crop that has escaped cultivation in some subtropical and warm temperate regions. Kudzu has previously demonstrated broad intraspecific physiological plasticity while colonizing new environments. The objective of this paper was to investigate characteristics of kudzu leaflet anatomy that might contribute to its successful growth in climatically distinct environments, and to escape cultivation as well. Fresh and fixed leaflet strips of field-grown plants were analyzed. The lower epidermis of kudzu showed a higher frequency of stomata $\left(147 \pm 19\right.$ stomata $\left.\mathrm{mm}^{-2}\right)$ than the upper epidermis $\left(26 \pm 17\right.$ stomata $\left.\mathrm{mm}^{-2}\right)$. The average number of trichomes per square milimeter was 8 for both the upper and the lower epidermis. The average trichome length was $410 \pm 200 \mu \mathrm{m}$ for the upper epidermis and $460 \pm 190 \mu \mathrm{m}$ for the lower epidermis. Cuticle thickness was not considerably different between lower and upper epidermis. The leaflet blade consisted basically of two layers (upper and lower) of unicellular epidermis, two layers of palisade parenchyma and one layer of spongy parenchyma. One layer of paraveinal mesophyll was found between palisade and spongy parenchyma. In conclusion, leaflets of kudzu present anatomical characteristics that might contribute to the broad physiological plasticity shown by kudzu.
\end{abstract}

Index terms: cuticle thickness, ecophysiology, leaflet anatomy, stomata, trichomes.

\section{ASPECTOS DA ANATOMIA FOLIAR DE PUERARIA LOBATA (LEGUMINOSAE-FABOIDEAE) ASSOCIADOS AO BALANÇO DE ÁGUA E DE ENERGIA}

\begin{abstract}
RESUMO - Kudzu é uma cultura de cobertura que se tornou invasiva em algumas regiões subtropicais e temperadas. Kudzu tem demonstrado ampla plasticidade fisiológica quando coloniza novos ambientes. Este trabalho teve por objetivo investigar características da anatomia foliar de kudzu que poderiam contribuir para seu hábito invasivo e também para sua propagação em ambientes distintos do ponto de vista climático. Foram analisados cortes frescos e permanentes de lâminas foliares de plantas crescidas no campo. A epiderme inferior tipicamente apresentou maior freqüência de estômatos $\left(147 \pm 19\right.$ estômatos $\left.\mathrm{mm}^{-2}\right)$ do que a epiderme superior $\left(26 \pm 17\right.$ estômatos $\left.\mathrm{mm}^{-2}\right)$. O número médio de tricomas por milímetro quadrado foi 8 para ambas, epiderme superior e epiderme inferior. O comprimento médio dos tricomas foi $410 \pm 200 \mu \mathrm{m}$ para a epiderme superior e $460 \pm 190 \mu \mathrm{m}$ para a epiderme inferior. A espessura da cutícula não diferiu significativamente entre as epidermes inferior e superior. A lâmina foliar consistiu basicamente de duas camadas de parênquima paliçádico e uma camada de parênquima lacunoso. Uma camada de mesófilo paranerval foi encontrada entre os parênquimas paliçádico e lacunoso. Concluindo, folíolos de kudzu apresentam características anatômicas que podem contribuir para a ampla plasticidade fisiológica demonstrada pela espécie.
\end{abstract}

Termos para indexação: anatomia de folíolos, tricomas, ecofisiologia, espessura de cutícula, estômatos.

1 Accepted for publication on October 29, 1998.

2 Biologist, Dr., Dep. de Botânica, S. Ciências Biológicas, Universidade Federal do Paraná (UFPR), CEP 81531-970 Curitiba, PR, Brazil. E-mail: apereira@bio.ufpr.br

${ }^{3}$ Biologist, Dr., Dep. de Morfol. e Sistemática Vegetais, Univ. Estadual de Campinas (UNICAMP), CEP 13081-000 Campinas, SP, Brazil.

${ }^{4}$ Agronomist, Dr., Dep. de Fisiologia Vegetal, UNICAMP.

\section{INTRODUCTION}

Pueraria lobata (Willd.) Ohwi (kudzu) is a perennial fast growing twining vine native to temperate and subtropical regions in eastern Asia. Kudzu is a nitrogen fixing cover crop used as forage throughout the subtropics and in some warm temperate regions (Bogdan, 1977). Kudzu serves as ex- 
cellent soil cover, is suitable for erosion-and weedcontrol, and provides good hay and pasture (Allen \& Allen, 1981). In the United States, kudzu escaped cultivation and is the most important weed associated with forestry (Carter et al., 1989). Kudzu now is considered a noxious weed, and interest has shifted towards its control and eradication (Forseth \& Teramura, 1987). However, more recent research focusing on the possible utilization of kudzu for the recovery of eroded and low fertility soils has been carried out (Lynd \& Ansman, 1990).

Although kudzu is not native to regions characterized by the transition between tropical and subtropical climates, this species has been well established in small areas in southeastern Brazil. Kudzu has previously demonstrated broad intraspecific physiological plasticity while colonizing new environments and this physiological plasticity certainly contributed to its successful establishment in southeastern Brazil.

The objective of this paper was to describe characteristics of leaflet anatomy related to water and energy budget in kudzu in order to support parallel ecophysiological studies designed to elucidate the mechanisms that are responsible for the ability of this species to escape cultivation and also the mechanisms that enable this species to grow successfully in climatically different environments. The manner in which these anatomical characteristics may relate to the plant's ability to grow and eventually compete in non-native areas (climatically distinct from its center of origin) such as biomes located at the border between the subtropical and tropical regions is also discussed.

\section{MATERIAL AND METHODS}

\section{Plant material}

A kudzu [Pueraria lobata (Willd.) Ohwi, Leguminosae-Faboideae] stand established at the experimental station Instituto Agronômico of the Campinas, SP, Brazil (lat. 22 49' S; long. $47^{\circ} 06^{\prime} \mathrm{W}$; altitude $669 \mathrm{~m}$ ) was used in this study. Plants were propagated from cuttings and field-grown in haplortox soil without irrigation or fertilization.

Only the uppermost completely expanded terminal leaflet from plants grown during the month of December (summer) was used in this study.

\section{Frequency of stomata}

The upper and lower epidermis of ten terminal leaflets of ten plants (one leaflet per plant) were washed in distilled water and rapidly peeled off, at a sharp angle to the epidermis of the leaflet. They were then immersed in $50 \%(\mathrm{v} / \mathrm{v})$ ethanol, for ten minutes, followed by immersion in $1 \%(\mathrm{v} / \mathrm{v})$ sodium hypochlorite to complete tissue bleaching. Sections of the lower and upper epidermis measuring about $1 \mathrm{~cm}^{2}$ were rinsed in distilled water and colored with toluidine blue. Each peel was placed on a slide and examined with a light microscope (Carl Zeiss, Germany). One hundred and fifty randomly chosen microscopic fields were used to determine the number of stomata per unit of area. Each field included $0.18 \mathrm{~mm}^{2}$ at $400 \mathrm{X}$ magnification.

\section{Frequency and length of trichomes}

Leaflet segments $\left(2 \mathrm{~cm}^{2}\right)$ were maintained under pressure between two glass slides. Thirty randomly chosen stereomicroscopic (Carl Zeiss, Germany) fields for ten leaflets of ten plants (one leaflet per plant) were used for countings and measurements of trichomes in both epidermis. Each field included $20 \mathrm{~mm}^{2}$ at $40 \mathrm{X}$ magnification. Trichome measurements were performed on three indiscriminately selected trichomes, in each stereomicroscopic field, with the help of a micrometric ocular.

\section{Cuticle thickness}

Fresh leaflet cross-sections were treated with ethanol and sodium hypochlorite, as described above (frequency of stomata), and colored with Sudan IV. The cuticle thickness of the upper and lower epidermis of thirty leaflet sections of six leaflets of six plants (one leaflet per plant) was measured through a light microscope (Carl Zeiss, Germany) supplied with a filar micrometric eye-piece.

\section{Leaflet structure}

Leaf strips were fixed in 70\% FAA (formalin:acetic acid:ethanol; 5:5:90), dehydrated in ethanol, immersed in a xylene series and imbibed in paraffin. Thin lamina crosssections were cut from the strips with a microtome, and afterwards paraffin was removed. Tissue was stained with toluidine blue $(0.05 \%$, aqueous solution), and after that, dehydrated through an ethanolic series. Photomicrographs of thirty slides of six leaflets of six plants (one leaflet per plant) were taken using a Carl Zeiss-2 (Germany) light microscope. 


\section{RESULTS AND DISCUSSION}

\section{Frequency of stomata}

On the average, the lower epidermis showed a number of stomata per square millimeter (frequency of stomata) equal to $147 \pm 19$ ( $\bar{X} \pm$ sd), while the upper epidermis showed a frequency of stomata equal to $26 \pm 17$ ( $\overline{\mathrm{X}} \pm \mathrm{sd})$.

Stomatal frequencies found in this study were lower when compared to stomatal frequencies found for glasshouse-grown plants of tropical kudzu (Pueraria phaseoloides) (Pereira Netto et al., 1997). The occurrence of stomata on the upper and lower leaf epidermis has been considered as an adaptive mechanism to maximize leaf conductance to $\mathrm{CO}_{2}$ when light and water are not limiting factors (Mott et al., 1982). So, amphistomatic leaflets, as found in this study, might indicate an elevated capacity to accumulate photoassimilates, through the potentially higher photosynthetic rates. Low stomata frequency on the upper epidermis can be beneficial by increasing water use efficiency, through the reduction of water loss, when high light intensity strikes the upper epidermis and by increasing the internal $\mathrm{CO}_{2}$ concentration of the leaf (Kramer, 1969; Monteiro et al., 1985).

\section{Frequency and length of trichomes}

Similar to stomata, trichomes were present on the lower and the upper epidermis (Table 1). The frequency of trichomes was the same for both lower and upper epidermis. Lower epidermis trichomes were barely longer when compared to those of the upper epidermis.

Leaf trichomes have been considered as an important ecophysiological factor contributing to an

TABLE 1. Frequency and length of trichomes on the upper and lower epidermis ${ }^{1}$.

\begin{tabular}{lcc}
\hline Epidermis & $\begin{array}{c}\text { Frequency } \\
\left(\text { trichomes } \mathrm{mm}^{-2}\right)\end{array}$ & $\begin{array}{c}\text { Length } \\
(\mu \mathrm{m})\end{array}$ \\
\hline Upper & $8 \pm 2$ & $410 \pm 200$ \\
Lower & $8 \pm 2$ & $460 \pm 190$ \\
\hline
\end{tabular}

${ }^{1}$ Numbers refer to mean \pm standard deviation. increase in the leaf boundary layer resistance (Ehleringer, 1985). The expansion of the boundary layer in pubescent leaves allows reduction of excessive water losses, especially under high wind speed, when compared to non-pubescent leaves (Schuepp, 1993). The effects of increased aerodynamic resistance on the photosynthetic rates would be expected to be relatively less significant, compared with the corresponding effect on transpiration or heat transfer, because of the larger mesophyll resistance to $\mathrm{CO}_{2}$ exchange. Not surprisingly, water-use-efficiency (amount of $\mathrm{CO}_{2}$ fixed in relation to the amount of water lost) has been found to be positively related to frequency of trichomes ( Schuepp, 1993).

The increase in the boundary layer can also aid in the maintenance of an optimum leaflet temperature since the presence of trichomes can significantly change the energy budget of leaves. Pubescent and non-pubescent leaves can be respectively $11^{\circ} \mathrm{C}$ and $5^{\circ} \mathrm{C}$ warmer than air, when the air temperature is $5^{\circ} \mathrm{C}, 6^{\circ} \mathrm{C}$ and $3^{\circ} \mathrm{C}$ warmer than air when the air temperature is $20^{\circ} \mathrm{C}$ (Meinzer \& Goldstein, 1985).

The increase in leaf reflectance due to the presence of trichomes might have a protective effect through the avoidance of thermal and photoinhibitory damage of the photosynthetic apparatus in leaflets subjected to excessive light intensity, which would be especially useful during cold weather, and excessive heat load, when leaflets would be exposed to direct solar radiation during warm weather.

The climbing mechanics presented by vines are related to the physiological adaptation to high light intensity environments (Carter \& Teramura, 1988). Consequently, the presence of trichomes might be useful for the reflectance of part of the excessive light intensity (at midday) and for the reduction of the heat load, particularly when light intensity is very high and heat loss through convection is low (low wind speed).

\section{Cuticle thickness}

Cuticle thickness of the upper epidermis of kudzu measured $0.9 \pm 0.3 \mu \mathrm{m}(\overline{\mathrm{X}} \pm \mathrm{sd})$, while cuticle thickness of the lower epidermis, measured $1.0 \pm 0.4 \mu \mathrm{m}$ $(\overline{\mathrm{X}} \pm \mathrm{sd})$.

Pesq. agropec. bras., Brasília, v.34, n.8, p.1361-1365, ago. 1999 
Cuticle thickness of about $1 \mu \mathrm{m}$ is comparable to cuticle thickness of other mesophytic species (Ashton \& Berlyn, 1992) and is thin if compared to cuticle thickness of plants found in dry environments such as Opuntia wentiana (cuticle thickness ranging between 115 and $150 \mu \mathrm{m}$ ) (Medina, 1987). High rates of water flow through the epidermis has been inversely related to cuticle thickness (Martin, 1994). However, Ashton \& Berlyn (1992) found no relationship between cuticle thickness and drought tolerance among three species of Quercus. In addition, other studies have demonstrated that chemical composition and the pattern of deposition of hydrophobic compounds in the cuticle might be the main factors reducing epidermal transpiration instead of cuticle thickness (Price, 1982).

\section{Leaflet structure}

Kudzu presented a tissue distribution typical of mesophytic species. The upper and lower epidermis were unicellular. Palisade parenchyma consisted of two cell layers while spongy parenchyma consisted of one cell layer. Between the palisade and the spongy parenchyma a layer of paraveinal mesophyll was found. The stomata, present in the upper and lower epidermis, were located at the same level in the epidermis layer (Fig. 1), showing small sub-sto-

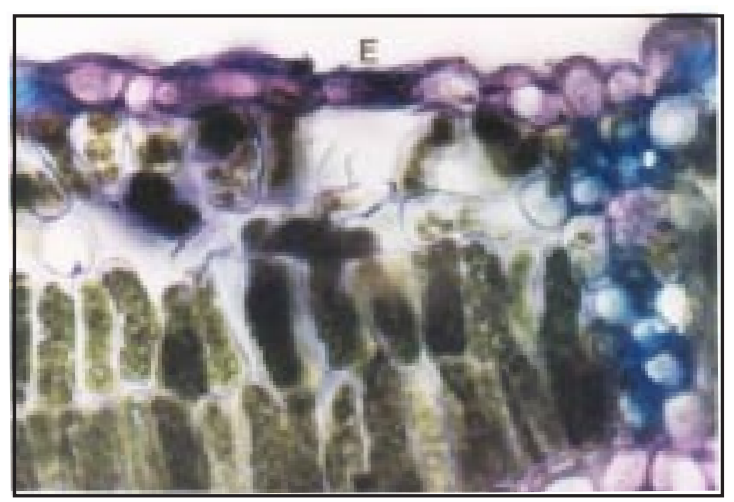

FIG. 1. Fresh cross section of the lower epidermis of Pueraria lobata (E: lower epidermis; S: longitudinal section of stoma; PP: palisade parenchyma; SP: spongy parenchyma; PM: paraveinal mesophyll; C: substomatal chambers. Vertical bar measures $10 \mu \mathrm{m})$. matal chambers. Neither secretory nor structures that characterize adaptations to dry environments were found. The analyses of the kinds of tissues and the distribution of these tissues found in the leaflet blades in this study demonstrate that kudzu leaflets do not present internal characteristics especially useful for the adaptation of this crop to warmer and drier environments.

\section{CONCLUSION}

Kudzu presents anatomical features, such as amphistomatic leaflets and trichomes, that may contribute to its invasive habit and to its adaptation to regions climatically distinct from its center of origin.

\section{ACKNOWLEDGEMENTS}

To Mrs. S. dos Santos and A. L. Moreira for their technical assistance and to Dr. William A. Russin, for reviewing the manuscript.

\section{REFERENCES}

ALLEN, O.N.; ALLEN, E.K. The leguminosae - A source book of characteristics, uses, and nodulation. Madison: The University of Wisconsin Press, 1981. 812p.

ASHTON, P.M.S.; BERLYN, G.P. Leaf adaptations of some Shorea species to sun and shade. New Phytologist, v.121, p.587-596, 1992.

BOGDAN, A.V. Tropical pasture and fodder plant: grasses and legumes. London: Longman, 1977. p.391-392.

CARTER, G.A.; TERAMURA, A.H. Vine photosynthesis and relationships to climbing mechanics in a forest understory. American Journal of Botany, v.75, p.1011-1018, 1988.

CARTER, G.A.; TERAMURA, A.H.; FORSETH, I.N. Photosynthesis in an open field for exotic versus native vines of the southeastern United States. Canadian Journal of Botany, v.67, p.443-446, 1989.

EHLERINGER, J. Annuals and perennials of warm deserts. In: CHABOT, B.F.; MOONEY, H.A. 
(Eds.). Physiological Ecology of North American Plant Communities. New York: Chapman and Hall, 1985. p.162-180.

FORSETH, I.N.; TERAMURA, A.H. Field photosynthesis, microclimate and water relations of an exotic temperate liana, Pueraria lobata, kudzu. Oecologia, v.71, p.262-267, 1987.

KRAMER, P.J. Plant and soil water relationships: a modern synthesis. New York: McGraw-Hill, 1969. 482p.

LYND, J.Q.; ANSMAN, T.R. Exceptional forage regrowth, nodulation and nitrogenase activity of kudzu (Pueraria lobata (Willd.) Ohwi) grown on eroded Dougherty loam subsoil. Journal of Plant Nutrition, v.13, p.861-886, 1990

MARTIN, C.E. Physiological ecology of the bromeliaceae. The Botanical Review, v.60, p.1-82, 1994.

MEDINA, E. Aspectos ecofisiológicos de plantas CAM en los trópicos. Revista de Biología Tropical, v.35, p.55-70, 1987.

MEINZER, F.; GOLDSTEIN, G. Some consequences of leaf pubescence in the Andean giant rosette plant
Espeletia timotensis. Ecology, v.66, p.512-520, 1985.

MONTEIRO, W.R.; CASTRO, M.M.; GIULIETTI, A.M. Aspects of leaf structure of some species of Leiothrix Ruhl. (Eriocaulaceae) from the Serra do Cipó (Minas Gerais, Brazil). Revista Brasileira de Botânica, v.8, p.109-125, 1985.

MOTT, K.A.; O'LEARY, J.W.; GIBSON, A.C. The adaptative significance of amphistomatic leaves. Plant Cell and Environment, v.5, p.455-460, 1982.

PEREIRA-NETTO, A.B. de; GABRIELE, A.C.; PINTO, H.S. Aspects of leaf anatomy of tropical kudzu related to water and energy balance. Pesquisa Agropecuária Brasileira, Brasília, v.32, n.7, p.689693, jul. 1997.

PRICE, C.E. A review of the factors influencing the penetration of pesticides through plant leaves. In: CUTLER, D.F.; ALVIN, K.L.; PRICE, C.E. (Eds.). The Plant Cuticle. London: Academic, 1982. p.237252.

SCHUEPP, P.H. Leaf boundary layers. New Phytologist, v.125, p.477-507, 1993. 